\title{
Risk of esophagus cancer in diabetes mellitus: a population-based case-control study in Taiwan
}

\author{
Kao-Chi Cheng ${ }^{1}$, Yu-Lung Chen', Shih-Wei Lai ${ }^{1,2}$, Pang-Yao Tsai ${ }^{3,4}$ and Fung-Chang Sung ${ }^{3,4^{*}}$
}

\begin{abstract}
Background: Diabetes mellitus (DM) has been associated with the cancer risk. This study investigated relationship between DM and esophageal cancer using Taiwan's insurance data.

Methods: We identified 549 patients with esophageal cancer newly diagnosed in 2000-2009 and randomly selected 2196 controls without any cancer, frequency matched by sex, age and diagnosis year of cases. Logistic regression model estimated odds ratios (ORs) and 95\% confidence intervals (Cl) of esophageal cancer associated with DM, sex, age. co-morbidities and medications.

Results: Cases were more prevalent than controls for alcoholism and esophageal disorders and using nonsteroidal anti-inflammatory drugs (NSAIDs) and cyclooxygenase-2 inhibitors but not DM. Esophageal cancer had no association with DM (OR 0.99, 95\% Cl 0.71-1.37), but significantly associated with alcoholism (OR 14.1, 95\% Cl 7.8725.4), esophageal ulcer (OR 10.1,95\% Cl 5.70-17.9), esophageal reflux (OR 3.47, 95\% Cl 2.14-5.26) and uses of NSAIDs (OR 2.73, 95\% Cl 1.80-4.13). An elevated risk of esophageal cancer appeared in DM patients taking insulin (OR 2.57, $95 \% \mathrm{Cl} 1.08-6.15)$ or sulfonyurea (OR 3.80, 95\% Cl 1.16-12.5).
\end{abstract}

Conclusions: Patients with DM are not at higher risk for esophagus cancer. However, esophageal disorders and anti-diabetic drugs are associated with the risk of the disease.

Keywords: Case-control study, Diabetes, Esophagus cancer, Insulin

\section{Background}

Glucose metabolism disorders (GMDs) such as diabetes mellitus (DM), impaired fasting glucose regulation (IFG), impaired glucose intolerance (IGT), and hypoglycemia are systemic diseases that have been associated with many other diseases including malignancy [1]. The estimated prevalence of diabetes for all ages worldwide may increase from $2.8 \%$ in 2000 to $4.4 \%$ in 2030 [2]. DM is also a prevalent public health problem in Taiwan. According to statistics, the mortality rates from DM have almost doubled over the past 10 years in Taiwan. The prevalence of DM in Taiwan has been higher than 5\% since 1985 [3]. Studies have associated DM with increased risk of cancers, such as esophageal cancer, hepatocellular carcinoma, bladder cancer, kidney cancer,

\footnotetext{
* Correspondence: fcsung1008@yahoo.com

${ }^{3}$ Management Office for Health Data, China Medical University Hospital,

Taichung 404, Taiwan

${ }^{4}$ Department of Public Health, China Medical University, Taichung 404, Taiwan

Full list of author information is available at the end of the article
}

breast cancer, and endometrial cancer [4-11]. The risk of esophageal cancer linking with DM has been controversy. A meta-analysis, including 6 case-control studies and 11 cohort studies, found a summary relative risk of 2.72 (95\% confidence interval (CI) 1.01-4.46) for esophageal cancer linking with DM [8].

Esophagus cancer incidence has been rising rapidly in many countries [12-16]. The incidence of esophageal adenocarcinoma rose approximately sixfold in the United States from 1975 to 2001 [15]. The 5-year mortality rates may exceed $80 \%$ for patients with the cancer [17]. Histological data have shown that populations with esophageal cancer in the Western countries suffer mainly from the adenocarcinoma [12-17]. Population in Taiwan has exactly the other type of esophageal cancer; approximately $95 \%$ patients have the squamous cell carcinoma [18]. The association between squamous cell carcinoma and DM in the Taiwan population may be different from that between adenocarcinoma and DM in the Western populations. This study was designed to use

\section{Biomed Central}

(c) 2012 Cheng et al.; licensee BioMed Central Ltd. This is an Open Access article distributed under the terms of the Creative Commons Attribution License (http://creativecommons.org/licenses/by/2.0), which permits unrestricted use, distribution, and reproduction in any medium, provided the original work is properly cited. 
the Taiwan National Health Insurance claims data to evaluate whether the squamous cell carcinoma of the esophagus is associated with DM.

\section{Methods \\ Data sources}

This case-control study used data available from the National Health Insurance (NHI) program in Taiwan. The insurance program was integrated from all public insurance programs in 1995 as a single payment program [19-22]. The National Health Research Institutes are responsible to management the claims data and converted the data into various data sets for research. This study used the claims data of inpatient and out-patients of 1million insured people randomly selected from all 23million population. Data files can be linked with scrambled identification to protect individual privacy. Information on anthropometry, laboratory tests and lifestyle was not available.

\section{Study subjects}

This study identified 549 patients aged 20 years and above newly diagnosed with esophageal cancer (ICD-9 150.X and V10.03) during the period of 2000-2009. The index date for each case was the date of diagnosis of esophageal cancer. For each esophageal cancer case, four controls were randomly selected from the same data set frequency matched by sex, age, and then the year the case being selected when controls having a health care visit in the same year. Subjects with esophageal cancer and any other cancer (ICD-9 140-208 and A-code A08xA14x) identified by the index year were excluded. We retrospectively screened to 1997 for the medical diagnosis of DM (ICD-9 250.xx and A-code A181) with prescription of DM medication for each selected subject. Similar process was performed to screen for comorbidities that may associate with the development of esophageal cancer. They were alcoholism (ICD-9 codes 303, 305.00, 305.01, 305.02, 305.03, and V11.3 and Acode A215), tobacco use disorders (ICD-9 codes 305.1X), periodontal disease (523.8 and 523.9X), HPV infection (079.4), hyperlipidemia (272.0, 272.1, 272.2, 272.3 and 272.4), Barrett's esophagus (530.85), esophageal ulcer $(530.2)$, esophageal reflux $(530.81,530.11)$ and esophageal burn (947.2). Other factors examined were the use of nonsteroidal anti-inflammatory drugs (NSAIDs) like aspirin, cyclooxygenase-2 inhibitors (COX-2 inhibitors) and anti-diabetic drugs identified from the prescription files. The anti-diabetic drugs included metformin, sulfonylureas, thiazolidinediones, alpha-glucosidase inhibitors, D-phenylalanine derivatives, dipeptidyl peptidase 4 inhibitors, incretin mimetic agents and insulins.

\section{Statistical analysis}

We compared the distributions in sex, age, comorbidities and medications between esophageal cancer cases and controls and tested differences using the Chisquare test. The significant variables were further included in the multivariate logistic regression analysis to measure odds ratio (OR) and 95\% CI for esophageal cancer, with diabetes status forced in the analysis. Further analyses explored whether the risk of esophageal cancer was associated with the duration of diabetes $(<2$ vs. $\geq 2$ years) and using anti-diabetic drugs. The association with anti-diabetic drug was estimated individually. The statistical significance level was set at probability value of $<0.05$ (SAS software version 9.1, SAS Institute Inc., Cary, North Carolina, USA).

\section{Ethical considerations}

This study used surrogate identification for each study subject to link study files to secure patient privacy. The present study was exempted from a full ethical review.

\section{Results}

\section{Baseline characteristics}

Table 1 compares the demographic characteristics and co-morbidities between esophageal cancer cases and controls. Both groups were predominantly men (92.9\%) with the mean age of 60.9 (standard deviations 3.03 vs. 12.9) years. There were no significant differences between cases and controls in the prevalence of DM $(10.4 \%$ vs. $10.1 \%, \mathrm{p}=0.85)$ and hyperlipidemia. Cases were more prevalent with co-morbidities of alcoholism, esophageal ulcer, esophageal reflux, and COX-2 inhibitors except use of other NSAIDs.

\section{Risk measures}

Table 2 shows that esophageal cancer was not related to DM in both univariate and multivariate logistic regression analyses (OR 0.99, 95\% CI 0.71-1.37). Among co-morbidities, esophageal cancer had the strongest association with alcoholism (OR 14.1, 95\% CI 7.87-25.4), followed by esophagus ulcer (OR 10.1, 95\% 5.70-17.9), esophagus reflux (OR 3.47, 95\% CI 2.14-5.62) and use of other NSAIDs (OR 2.73, 95\% CI 1.80-4.13). Table 2 also shows a protective association between periodontal disease and esophageal cancer (OR 0.20, 95\% CI 0.02-0.88).

Table 3 shows patients with DM for longer than 2 years were at higher risk of the cancer than patients with shorter DM history with an OR of 2.28 (95\% CI 0.856.08) after controlling for sex, age, alcoholism, periodontal disease, esophagus ulcer, esophagus reflux, COX-2 inhibitors and other NSAIDs. 
Table 1 Comparisons in socio-demographic status, comorbidity and medication between esophageal cancer cases and controls frequency matched by sex, age and index year

\begin{tabular}{|c|c|c|c|c|c|}
\hline & \multicolumn{4}{|c|}{ Esophageal cancer } & \multirow[b]{3}{*}{$P$ value $^{t}$} \\
\hline & \multicolumn{2}{|c|}{$\begin{array}{c}\text { No } \\
\mathrm{N}=2196 \\
\end{array}$} & \multicolumn{2}{|c|}{$\begin{array}{c}\text { Yes } \\
N=549\end{array}$} & \\
\hline & $\mathbf{n}$ & $\%$ & $\mathrm{n}$ & $\%$ & \\
\hline Age, mean (SD), years & 60.9 & (3.03) & 60.9 & $(12.9)$ & 0.24 \\
\hline $20-39$ & 56 & 2.55 & 14 & 2.55 & 1.00 \\
\hline $40-64$ & 1,328 & 60.5 & 332 & 60.5 & \\
\hline$\geq 65$ & 812 & 37.0 & 203 & 37.0 & \\
\hline Sex & & & & & 1.00 \\
\hline Women & 156 & 7.10 & 39 & 7.10 & \\
\hline Men & 2,040 & 92.9 & 510 & 92.9 & \\
\hline \multicolumn{6}{|l|}{ Comorbidity } \\
\hline Diabetes mellitus & 222 & 10.1 & 57 & 10.4 & 0.85 \\
\hline Alcoholism & 16 & 0.73 & 53 & 9.65 & $<0.0001$ \\
\hline Obesity & 4 & 0.18 & 1 & 0.18 & $1.00^{\dagger}$ \\
\hline Tobacco use disorder & 7 & 0.32 & 5 & 0.91 & $0.07^{\dagger}$ \\
\hline Periodontal disease & 33 & 1.50 & 2 & 0.36 & $0.03^{+}$ \\
\hline HPV infection & - & - & - & - & - \\
\hline Hyperlipidemia & 324 & 14.8 & 65 & 11.8 & 0.08 \\
\hline Barrett's esophagus & - & - & - & - & - \\
\hline Esophageal ulcer & 18 & 0.82 & 50 & 9.11 & $<0.0001$ \\
\hline Esophageal reflux & 39 & 1.78 & 43 & 7.83 & $<0.0001$ \\
\hline \multicolumn{6}{|l|}{ Medication } \\
\hline Use of aspirin & 305 & 13.9 & 83 & 15.1 & 0.46 \\
\hline Use of COX-2 inhibitors & 495 & 22.5 & 159 & 29.0 & 0.002 \\
\hline Use of other NSAIDs & 1,877 & 85.5 & 522 & 95.1 & $<0.0001$ \\
\hline
\end{tabular}

Data are presented as the number of subjects in each group, with percentages given in parentheses.

Chi-square test and ${ }^{\dagger}$ Fisher's exact test comparing patients with and without esophageal cancer.

\section{Influence of anti-diabetic drugs}

Data analysis showed that patients taking anti-diabetic drugs were at higher risk of esophageal cancer (Table 4). The associations were significant for insulin (OR 2.58, 95\%1.08-6.15) and sulfonylureas (OR 3.80, 95\% 1.16$12.5)$, and moderately significant for metformin.

\section{Discussion}

Studies investigating the relationship between malignancy and DM have revealed conflicting results on the association between DM and esophagus cancer, and other cancers [8,23-39]. Based on histology, the distribution of squamous cell carcinoma and adenocarcinoma varies among different geographic areas. Most of studies on esophageal cancer have been conducted on
Table 2 Crude and adjusted odds ratios and $95 \%$ confidence intervals of esophageal cancer associated with diabetes and covariates

\begin{tabular}{|c|c|c|c|c|}
\hline \multirow[b]{2}{*}{ Variable } & \multicolumn{2}{|c|}{ Crude } & \multicolumn{2}{|c|}{ Adjusted } \\
\hline & OR & $(95 \% \mathrm{Cl})$ & OR & $(95 \% \mathrm{Cl})$ \\
\hline \multicolumn{5}{|c|}{ Diabetes mellitus } \\
\hline No & 1.00 & & 1.00 & \\
\hline Yes & 1.03 & $(0.76-1.40)$ & 0.99 & $(0.71-1.37)$ \\
\hline \multicolumn{5}{|l|}{ Alcoholism } \\
\hline No & 1.00 & & 1.00 & \\
\hline Yes & 14.6 & $(8.25-25.7)$ & 14.1 & $(7.87-25.4)$ \\
\hline \multicolumn{5}{|c|}{ Periodontal disease } \\
\hline No & 1.00 & & 1.00 & \\
\hline Yes & 0.24 & $(0.06-1.00)$ & 0.20 & $(0.04-0.88)$ \\
\hline \multicolumn{5}{|c|}{ Esophageal ulcer } \\
\hline No & 1.00 & & 1.00 & \\
\hline Yes & 12.1 & $(7.01-21.0)$ & 10.1 & $(5.70-17.9)$ \\
\hline \multicolumn{5}{|c|}{ Esophageal reflux } \\
\hline No & 1.00 & & 1.00 & \\
\hline Yes & 4.70 & $(3.02-7.33)$ & 3.47 & $(2.14-5.62)$ \\
\hline \multicolumn{5}{|c|}{ COX-2 inhibitors } \\
\hline Never use & 1.00 & & 1.00 & \\
\hline Ever use & 1.40 & $(1.14-1.73)$ & 1.06 & $(0.83-1.34)$ \\
\hline \multicolumn{5}{|c|}{ Other NSAIDs } \\
\hline Never use & 1.00 & & 1.00 & \\
\hline Ever use & 3.28 & $(2.19-4.92)$ & 2.73 & $(1.80-4.13)$ \\
\hline
\end{tabular}

Adjusted for sex, age, DM, alcoholism, periodontal disease, esophagus ulcer, esophagus reflux, other NSAIDs and COX-2 inhibitors.

adenocarcinoma of the esophagus for the populations in Western countries [8,23-42]. The positive association between the risk of esophagesl cancer and DM in the meta-analysis conducted by Huang et al consisted of 15 studies from Western countries and two studies from Asian countries [8]. More than $80 \%$ of esophagus cancer cases in the Asian are squamous cell carcinoma [18]. Whether the risk of squamous cell carcinoma of esophagus has a relationship with DM has not been well explored. Our study makes up for the gap because the previous study found that the squamous cell carcinoma is the major type of esophageal cancer in Taiwan, accounting as high as $95 \%$ of patients with the disease [18].

The present population-based case-control study failed to find a significant association between DM and esophagus cancer in Taiwan. Regardless no association was found between DM and esophageal cancer, this study shows several co-morbidities were much more prevalent in cases than in controls. Consistent with other studies [26,27,37-39], we also found heavy alcohol 
Table 3 Adjusted odds ratios for esophageal cancer in relation to duration of diabetes mellitus

\begin{tabular}{|c|c|c|c|c|}
\hline \multirow{2}{*}{$\begin{array}{l}\text { Duration of } \\
\text { diabetes (years) }\end{array}$} & Case & Control & \multicolumn{2}{|c|}{ Odds ratio $(95 \% \mathrm{Cl})$} \\
\hline & \multicolumn{2}{|c|}{ Number (\%) } & Model 1 & Model 2 \\
\hline $0-2$ & 6 & 44 & 1.00 & 1.00 \\
\hline$\geq 2$ & 51 & 178 & $2.10(0.85-5.31)$ & $2.28(0.85-6.08$ \\
\hline
\end{tabular}

Model 1 was adjusted for age and sex.

Model 2 was additionally adjusted for sex, age, alcoholism, periodontal disease, esophagus ulcer, esophagus reflux, other NSAIDs and COX-2 inhibitors.

drinking is the strongest risk factor associated with esophageal cancer. A Korean study found a relative risk of 5.62 for mortality from esophageal cancer [26]. Japanese have an OR of 15 for esophageal caner among high alcohol consumers [27]. The risk may increase further to approximately 70 -fold higher for those with alcohol flushing response, indicating individuals with difficulty to metabolite alcohol are at a much higher risk for the cancer. The exact mechanism of how alcoholic beverage is associated with esophagus cancer risk is not clear. Although ethanol has not been shown as carcinogenic in laboratory animals, it may act through its major metabolite, acetaldehyde, a carcinogen in animal models $[27,38,43-45]$. The dose-response relationship with alcohol strongly indicates it as an independent risk factor, particularly for esophagus squamous-cell cancer $[26,37,39]$.

Esophageal cancer is significantly associated with esophageal ulcer and esophageal reflux, and medications in this study. Both esophageal ulcer and esophageal reflux are likely the earlier signals for the subsequent development of the cancer of esophagus due to esophageal stricture formation, such as acid peptic and medication- induced. Peptic strictures account for most of esophageal strictures [46-49]. Purdy et al. found esophageal mucosa injury is associated with sloughing esophagitis, chronic debilitation and medications [46]. García Rodríguez et al. have also reported that long term pharmacological gastric acid suppression is associated with the risk of oesophageal and gastric adenocarcinoma [47]. In this study, anti-diabetes drugs and other NSAIDs are significantly associated with the disease.

\section{Limitations}

This study was conducted using insurance claims data, a few limitations should be considered. First, smoking is an important factor associated with esophageal cancer. But, this information is not available in the insurance claims. However, we are able to identify patients with the diagnosis of alcoholism. There is strong relationship between drinking and smoking. And we did find alcoholism is an indicator that may well predict the cancer. Second, this case-control study enrolled study subjects with and without esophageal cancer identified from 2000 to 2009. The frequency matched study design fails to observe age difference between cases and controls.

Table 4 Odds ratios of esophageal cancer in relation to use of anti-diabetic drugs

\begin{tabular}{|c|c|c|c|c|}
\hline \multirow[t]{2}{*}{ Use of anti-diabetic drugs } & \multirow[t]{2}{*}{ Case } & \multirow[t]{2}{*}{ Control } & \multicolumn{2}{|c|}{ Odds ratio $(95 \% \mathrm{Cl})$} \\
\hline & & & Model 1 & Model 2 \\
\hline \multicolumn{5}{|l|}{ Insulins } \\
\hline never use & $7(12.3)$ & $69(31.1)$ & 1.00 & 1.00 \\
\hline ever use & $50(87.7)$ & $153(68.9)$ & $3.27(1.40-7.60)$ & $2.58(1.08-6.15)$ \\
\hline \multicolumn{5}{|l|}{ Metformin } \\
\hline never use & $5(8.77)$ & 43(19.4) & 1.00 & 1.00 \\
\hline ever use & $52(91.2)$ & $179(80.6)$ & $2.34(0.87-6.24)$ & 2.84(0.99-8.18) \\
\hline \multicolumn{5}{|l|}{ Sulfonylureas } \\
\hline never use & $4(7.02)$ & $38(17.1)$ & 1.00 & 1.00 \\
\hline ever use & $53(92.9)$ & 184(82.9) & $2.75(0.94-8.10)$ & $3.80(1.16-12.5)$ \\
\hline \multicolumn{5}{|l|}{ Thiazolidinediones } \\
\hline never use & $49(86.0)$ & $180(81.1)$ & 1.00 & 1.00 \\
\hline ever use & $8(14.0)$ & $42(18.9)$ & $0.65(0.28-1.49)$ & $1.11(0.46-2.65)$ \\
\hline \multicolumn{5}{|l|}{ Alpha-glucosidase inhibitors } \\
\hline never use & $48(84.2)$ & $188(84.7)$ & 1.00 & 1.00 \\
\hline ever use & $9(15.8)$ & $34(15.3)$ & $1.00(0.44-2.24)$ & \\
\hline
\end{tabular}

Model 1 was adjusted for age and sex.

Model 2 was additionally adjusted for sex, age, alcoholism, periodontal disease, esophagus ulcer, esophagus reflux, other NSAIDs and COX-2 inhibitors. 
However, we have also conducted an unmatched analysis by randomly sampling controls, which revealed a mean age of 15.4 years younger in the controls. This analysis also showed that DM is not a factor associated with esophageal cancer. Therefore, the frequency matched samples are representative of the insured population. Finally, the insurance registry does not provide the information on histological type and genotype of the cancer. We were unable to differentiate whether the associated risk factors different between squamous cell carcinoma and adenocarcinoma among study subjects. It is likely that the small portion of adenocarcinoma may not change the association between DM and the risk of esophageal cancer in the present study.

\section{Conclusions}

In conclusion, the results of our study fail to show a significant association between DM and the risk of esophagus cancer. Instead, alcoholism, esophageal ulcer and esophageal reflux are significant predictors for the cancer. Patients of heavy drink, with esophageal ulcer, esophageal reflux and peptic strictures are at high risk of developing the disease.

\section{Competing interests}

The authors disclose no conflicts of interest.

\section{Authors' contribution \\ KCC: (1) substantial contributions to the conception of this article; (2) planned and conducted the study; (3) initiated the draft of the article and critically revised it; S-WL: (1) substantial contributions to the conception of this article; (2) planned and conducted the study; (3) initiated the draft of the article and critically revised it; Y-LC: (1) substantial contributions to the conception of this article; (2) initiated the draft of the article and critically revised it; P-YT: (1) conducted data analyses; (2) critically revised the article; F- CS: (1) substantial contributions to the study concept and design; (2) conducted data analysis and data interpretation; (3) critically revised the article. All authors read and approved the final manuscript.}

\section{Acknowledgements}

The authors (Guarantor's Name: Fung-Chang Sung) thank the National Health Research Institute in Taiwan for providing the insurance claims data.

\section{Funding}

This study was supported in part by grants from Taiwan Department of Health Clinical Trial and Research Center of Excellence (DOH101-TD-B-111004), the Cancer Research Center of Excellence (DOH 100-TD-C-111-005), the National Science Council (NSC 100-2621-M-039-001), and China Medical University Hospital (1MS1). The funding agencies did not influence the study design, data collection and analysis, decision to publish, or preparation of the manuscript.

\section{Author details}

'Department of Family Medicine, China Medical University Hospital, Taichung 404, Taiwan. ${ }^{2}$ School of Medicine, China Medical University, Taichung 404, Taiwan. ${ }^{3}$ Management Office for Health Data, China Medical University Hospital, Taichung 404, Taiwan. ${ }^{4}$ Department of Public Health, China Medical University, Taichung 404, Taiwan.

Received: 15 April 2012 Accepted: 7 December 2012

Published: 12 December 2012

\section{References}

1. Zhan YS, Feng L, Tang SH, Li WG, Xu M, Liu TF, Zhou YF, Ma YL, Zhang Y, Pu XM: Glucose metabolism disorders in cancer patients in a Chinese population. Med Oncol 2010, 27(2):177-184.

2. Wild S, Roglic G, Green A, Sicree R, King H: Global Prevalence of Diabetes Estimates for the year 2000 and projections for 2030. Diabetes Care 2004, 27:1047-1053.

3. Chang C, Lu F, Yang YC, Wu JS, Wu TJ, Chen MS, Chuang LM, Tai TY: Epidemiologic study of type 2 diabetes in Taiwan. Diabetes Res Clin Pract 2000, 50(Suppl 2):S49-S59.

4. Jee SH, Ohrr H, Sull JW, Yun JE, Ji M, Samet JM: Fasting serum glucose level and cancer risk in Korean men and women. JAMA 2005, 293:194-202.

5. Davila JA, Morgan RO, Shaib Y, McGlynn KA, El-Serag HB: Diabetes increases the risk of hepatocellular carcinoma in the United States: a population based case control study. Gut 2005, 54(4):533-539.

6. Inoue M, Iwasaki M, Otani T, Sasazuki S, Noda M, Tsugane S: Diabetes mellitus and the risk of cancer: results from a large-scale population-based cohort study in Japan. Arch Intern Med 2006, 166(17):1871-1877.

7. Larsson SC, Orsini N, Brismar K, Wolk A: Diabetes mellitus and risk of bladder cancer: a meta-analysis. Diabetologia 2006, 49(12):2819-2823.

8. Huang W, Ren H, Ben Q, Cai Q, Zhu W, Li Z: Risk of esophageal cancer in diabetes mellitus: a meta-analysis of observational studies. Canc Causes Contr 2012, 23(2):263-272.

9. Michels KB, Solomon CG, Hu FB, Rosner BA, Hankinson SE, Colditz GA, Manson JE: Type 2 diabetes and subsequent incidence of breast cancer in the Nurses' Health Study. Diabetes Care 2003, 26(6):1752-1758.

10. Saltzman BS, Doherty JA, Hill DA, Beresford SA, Voigt LF, Chen C, Weiss NS: Diabetes and endometrial cancer: an evaluation of the modifying effects of other known risk factors. Am J Epidemiol 2008, 167(5):607-614.

11. Kuriki $K$, Hirose $K$, Tajima $K$ : Diabetes and cancer risk for all and specific sites among Japanese men and women. Eur J Cancer Prev 2007, 16(1):83-89.

12. Blot WJ, Devesa SS, Kneller RW, Fraumeni JF Jr: Rising incidence of adenocarcinoma of the esophagus and gastric cardia. JAMA 1991, 265(10):1287-1289.

13. Wayman J, Forman D, Griffin SM: Monitoring the changing pattern of esophago-gastric cancer: data from a UK regional cancer registry. Canc Causes Contr 2001, 12(10):943-949.

14. Pera M, Manterola C, Vidal O, Grande L: Epidemiology of esophageal adenocarcinoma. J Surg Oncol 2005, 92(3):151-159.

15. Pohl H, Welch HG: The role of overdiagnosis and reclassification in the marked increase of esophageal adenocarcinoma incidence. J Natl Cancer Inst 2005, 97(2):142-146.

16. El-Serag HB, Mason AC, Petersen N, Key CR: Epidemiological differences between adenocarcinoma of the oesophagus and adenocarcinoma of the gastric cardia in the USA. Gut 2002, 50(3):368-372.

17. Holmes RS, Vaughan TL: Epidemiology and pathogenesis of esophageal cancer. Semin Radiat Oncol 2007, 17(1):2-9.

18. Chang SS, Lu CL, Chao JY, Chao Y, Yen SH, Wang SS, Chang FY, Lee SD: Unchanging trend of adenocarcinoma of the esophagus and gastric cardia in Taiwan: A 15-year experience in a single center. Digest Dis Sci 2002, 47(4):735-740.

19. Cheng TM: Taiwan's national health insurance system: High value for the dollar. Six Countries, Six Reform Models: the Healthcare Reform. Experience of Israel, the Netherlands, New Zealand, Singapore, Switzerland and Taiwan: Healthcare Reforms" under the Radar Screen"; 2010:171-204.

20. Lai SW, Liao KF, Liao CC, Muo CH, Liu CS, Sung FC: Polypharmacy correlates with increased risk for hip fracture in the elderly: a population-based study. Medicine (Baltimore) 2010, 89(5):295-299.

21. Lai SW, Muo CH, Liao KF, Sung FC, Chen PC: Risk of acute pancreatitis in type 2 diabetes and risk reduction on anti-diabetic drugs: a population-based cohort study in Taiwan. Am J Gastroenterol 2011, 106(9):1697-1704.

22. Lai SW, Su LT, Lin CH, Tsai CH, Sung FC, Hsieh DP: Polypharmacy increases the risk of Parkinson's disease in older people in Taiwan: a populationbased study. Psychogeriatrics 2011, 11(3):150-156.

23. Jiang $X$, Bernstein $L$, Tseng CC, Wu AH: Diabetes and risk of esophageal and gastric adenocarcinomas. Int J Cancer 2012, 131(6):1417-1422. 
24. Rubenstein JH, Davis J, Marrero JA, Inadomi JM: Relationship between diabetes mellitus and adenocarcinoma of the oesophagus and gastric cardia. Aliment Pharmacol Ther 2005, 22(3):267-271.

25. Atchison EA, Gridley G, Carreon JD, Leitzmann MF, McGlynn KA: Risk of cancer in a large cohort of U.S. veterans with diabetes. Int J Cancer 2011, 128(3):635-643.

26. Islami F, Fedirko V, Tramacere I, Bagnardi V, Jenab M, Scotti L, Rota M, Corrao G, Garavello W, Schüz J, Straif K, Negri E, Boffetta P, La Vecchia C: Alcohol drinking and esophageal squamous cell carcinoma with focus on light-drinkers and never-smokers: a systematic review and meta-analysis. Int J Cancer 2011, 129(10):2473-2484.

27. Brooks PJ, Enoch MA, Goldman D, Li TK, Yokoyama A: The alcohol flushing response: an unrecognized risk factor for esophageal cancer from alcohol consumption. PLoS Med 2009, 6(3):e50.

28. Seow A, Yuan JM, Koh WP, Lee HP, Yu MC: Diabetes mellitus and risk of colorectal cancer in the Singapore Chinese Health Study. J Natl Cancer Inst 2006, 98(2):135-138.

29. Calton BA, Chang SC, Wright ME, Kipnis V, Lawson K, Thompson FE, Subar AF, Mouw T, Campbell DS, Hurwitz P, et al: History of diabetes mellitus and subsequent prostate cancer risk in the NIH-AARP Diet and Health Study. Canc Causes Contr 2007, 18(5):493-503.

30. Chari ST, Leibson CL, Rabe KG, Timmons LJ, Ransom J, de Andrade M, Petersen GM: Pancreatic cancer-associated diabetes mellitus: prevalence and temporal association with diagnosis of cancer. Gastroenterology 2008, 134(1):95-101.

31. Perrin MC, Terry MB, Kleinhaus $K$, Deutsch $L$, Yanetz $R$, Tiram $E$, Calderon-Margalit R, Friedlander Y, Paltiel O, Harlap S: Gestational diabetes and the risk of breast cancer among women in the Jerusalem Perinatal Study. Breast Cancer Res Treat 2008, 108(1):129-135.

32. Lipscombe LL, Goodwin PJ, Zinman B, McLaughlin JR, Hux JE: The impact of diabetes on survival following breast cancer. Breast Cancer Res Treat 2008, 109(2):389-395.

33. Holroyde CP, Skutches CL, Boden G, Reichard GA: Glucose metabolism in cachectic patients with colorectal cancer. Cancer Res 1984, 44(12 Pt 1):5910-5913.

34. Blot WJ: Alcohol and cancer. Cancer Res 1992, 52(7 Suppl):2119s-2123s.

35. Ji BT, Dai Q, Gao YT, Hsing AW, McLaughlin JK, Fraumeni JF Jr, Chow WH: Cigarette and alcohol consumption and the risk of colorectal cancer in Shanghai, China. Eur J Cancer Prev 2002, 11(3):237-244.

36. La Vecchia C: Alcohol and liver cancer. Eur J Cancer Prev 2007, 16(6):495-497.

37. Vioque J, Barber X, Bolumar F, Porta M, Santibanez M, de la Hera MG, Moreno-Osset E: Esophageal cancer risk by type of alcohol drinking and smoking: a case-control study in Spain. BMC Cancer 2008, 8:221-230.

38. Fan Y, Yuan JM, Wang R, Gao YT, Yu MC: Alcohol, tobacco, and diet in relation to esophageal cancer: the Shanghai Cohort Study. Nutr Cancer 2008, 60(3):354-363.

39. Morita M, Kumashiro R, Kubo N, Nakashima Y, Yoshida R, Yoshinaga K, Saeki H, Emi Y, Kakeji Y, Sakaguchi Y, Toh Y, Maehara Y: Alcohol drinking, cigarette smoking, and the development of squamous cell carcinoma of the esophagus: epidemiology, clinical findings, and prevention. Int J Clin Oncol 2010, 15(2):126-134.

40. Kort EJ, Sevensma E, Fitzgerald TL: Trends in esophageal cancer and body mass index by race and gender in the state of Michigan. BMC Gastroenterol 2009, 9:47-53.

41. Bollschweiler E, Wolfgarten E, Gutschow C, Holscher AH: Demographic variations in the rising incidence of esophageal adenocarcinoma in white males. Cancer 2001, 92(3):549-555.

42. Zhang HY, Spechler SJ, Souza RF: Esophageal adenocarcinoma arising in Barrett esophagus. Cancer Lett 2009, 275(2):170-177.

43. Schottenfeld D, Beebe-Dimmer J: Alleviating the burden of cancer: a perspective on advances, challenges, and future directions. Cancer Epidemiol Biomarkers Prev 2006, 15(11):2049-2055.

44. Harris EL: Association of oral cancers with alcohol consumption: exploring mechanisms. J Natl Cancer Inst 1997, 89(22):1656-1657.

45. Homann N, Karkkainen P, Koivisto T, Nosova T, Jokelainen K, Salaspuro M: Effects of acetaldehyde on cell regeneration and differentiation of the upper gastrointestinal tract mucosa. J Natl Cancer Inst 1997, 89(22):1692-1697.

46. Purdy JK, Appelman HD, McKenna BJ: Sloughing esophagitis is associated with chronic debilitation and medications that injure the esophageal mucosa. Mod Pathol 2012, doi:10.1038/modpathol.2011.204 [Epub ahead of print].

47. García Rodríguez LA, Lagergren J, Lindblad M: Gastric acid suppression and risk of oesophageal and gastric adenocarcinoma: a nested case control study in the UK. Gut 2006, 55(11):1538-44. Epub 2006 Jun 19.

48. Ljung R, Martin L, Lagergren J: Oral disease and risk of oesophageal and gastric cancer in a nationwide nested case-control study in Sweden. Eur J Cancer 2011, 47(14):2128-2132.

49. Uno K, lijima K, Hatta W, Koike T, Abe Y, Asano N, Kusaka G, Shimosegawa T: Direct measurement of gastroesophageal reflux episodes in patients with squamous cell carcinoma by $24-\mathrm{h}$ pH-impedance monitoring. Am Gastroenterol 2011, 106(11):1923-1929.

doi:10.1186/1471-230X-12-177

Cite this article as: Cheng et al:: Risk of esophagus cancer in diabetes mellitus: a population-based case-control study in Taiwan. BMC Gastroenterology 2012 12:177.

\section{Submit your next manuscript to BioMed Central and take full advantage of:}

- Convenient online submission

- Thorough peer review

- No space constraints or color figure charges

- Immediate publication on acceptance

- Inclusion in PubMed, CAS, Scopus and Google Scholar

- Research which is freely available for redistribution 